\title{
Stand-up tragedy in Poland?
}

\author{
Wtadystaw Chtopicki
}

\begin{abstract}
The article first describes the cabaret tradition of Polish comedy, and then looks at various forms of stand-up that have been spreading in Poland over the last 20 years, mainly on TV, but some originating in newly established comedy clubs. Within the last twenty years, the new form of stand-up in its American variety has been slowly moving in. The characteristics of this new genre included precisely the topics which were excluded from the old form (such as explicit sex references and scatology) as well as the focus on the vernacular. The common features of stand-up included immediacy, playing cultural and linguistic kinship with the audience, impersonations, "shifting consensus", seeming spontaneity, and occasional self-deprecation. Young performers found a venue in the well known HBO show called Na stojaka ('While standing', which ran for ten years), as well as other venues such as the stand-up competition called Zabij mnie śmiechem ('Kill me with laughter') broadcast by the Polsat commercial channel since 2010 where the winner is rewarded with a trip to an American stand-up school.

The stand-up does not meet with universal appeal, as one comment found on the Internet clearly shows: it named the phenomenon a "stand-up tragedy". The Polish audiences largely believe that the performance must be first of all funny, and only then "authentic", while some young performers seem to play mainly on obscenity and scatology and forget the need to amuse. Therefore, even though the new form has been slowly gaining ground, the cabaret prevails both in some of the forms which it shares with stand-up (e.g. non-interactive monologues, which are no longer literary but colloquial, or impersonations) and also with regard to popular performers, who largely originate in cabaret or are well-known actors.
\end{abstract}

Keywords: stand-up, cabaret, Polish humour, scatology, improvisation

\section{Introduction}

Polish stage comedy tradition goes back to the $18^{\text {th }}$ century, when playwrights such as Wojciech Bogusławski and then Aleksander Fredro staged their social comedies of manners (cf. Wojtak 2012). The cabaret tradition started in the early $20^{\text {th }}$ century during the Young Poland period in art, when bohemian societies started springing up. This period in Poland was also that of strong 
pro-independence movements preceding the First World War, particularly active in the Austrian-occupied Galicia, which was due to a relative autonomy of the province and leniency of Austrian authorities. Kraków as the city of artists and intellectuals, who cherished and appreciated French culture, enjoyed particular freedom and this is one of the reasons that it is there that the cabaret first developed. It must be emphasised at the start that French cabaret filtered through to Poland as a form of sophisticated entertainment, which was based on elaborate literary texts, theatrical scenes or sketches, as well as songs and monologues - short, coherent performances of single performers, prepared beforehand and rehearsed. This did not mean, however, that the early cabaret had no decadent connection - socially it started as an artistic boheme, which is illustrated by the story of the first Polish cabaret, developed in the fin-de-siécle atmosphere of the turn of the $20^{\text {th }}$ century.

\section{The Little Green Balloon}

The first cabaret opened in Kraków in 1905 under the name of Zielony Balonik ('Little Green Balloon') and ran regular performances until 1911. It was hosted by Michalik pastry shop at Floriańska Street in Kraków Old Town, now a historical sight and working café known as Jama Michalika. Guests were admitted to the show by invitation only, so the audience formed a close elite circle, and the admittance to the cabaret events became highly desired in the town's middle class - a symbol of status. The performances were at first spontaneous and consisted of songs, poems, parodies, and sketches, later turning into prepared playbills. Every cabaret performance was a premiere and was never to be repeated again, so rumours spread around town about the goings-on in the cabaret, and devout ladies and matrons gossiped of orgies, naked dancing and general debauchery, which gave rise to the black legend of the cabaret (cf. Kiec 2004: 17). The focus of the cabaret was social satire on public figures, especially the Kraków conservative elite, and no politics was involved, which was understandable given the situation of foreign occupation and the presence of political censorship. As an extra feature of each performance, the first Polish compère, the playwright freshly returned from Paris, Jan August Kisielewski, prepared special rather insulting speeches to greet every newcomer to the audience, which were delivered on their entry into the café. This was a rite of passage of sorts to test if they can take a joke at their own expense. This is how the comic writer Tadeusz Boy Żeleński recalls the opening night of the cabaret on October 7, 1905: 
On that memorable evening the conferencier [announcer] was on the stage, wearing frock coat, white leggings, and started his speech half in Polish, half in French. He called the audience beasts, as was typical of an artist in front of fillisters. As a matter of fact, there were not many fillisters in the packed room, filled with artistic boheme; soon it turned out that the conferencier was thoroughly intoxicated and not with noble wine, but simply with vodka. His words turned into actions and he went for "well-fed bourgeois" with his bare hands, the embodiment of whom he saw in the person of the imposing fatso-Stanistawski, the painter. That kind-hearted giant disarmed the attacker, who was put to sleep, but the young cabaret was left without the visible head. The rest of the evening was filled with improvisations, choir drinking songs and of course drinking (after Kiec 2004: 13; author's translation).

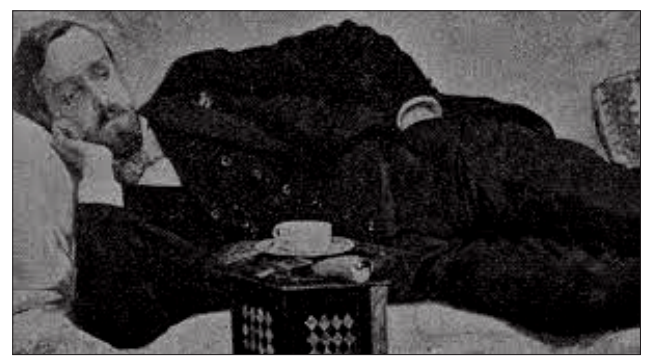

Figure 1. Jan August Kisielewski. Portrait by Edward Loewy. Source: Wikipedia.

The Little Green Balloon cabaret set the example, and other cabarets proliferated both in Kraków and other cities, especially after Poland became independent in 1918. A notable example was the Qui pro Quo cabaret of Warsaw active in the years 1919-1931. This was also a literary cabaret, with social and political satire (politics was welcome as a subject of ridicule at the time), with poems and songs, some of which were written by Julian Tuwim, the famous poet of Jewish origin, fully assimilated into Polish culture, one of the best loved Polish poets of the $20^{\text {th }}$ century. The cabaret also excelled at the szmonces (from Yiddish 'nonsense', hence Jewish jokes), and the szlagier (hit songs). 


\section{The Cellar Under the Rams}

In Kraków, the cabaret tradition thrived during the interwar period and in the 1950s the literary cabaret known as Piwnica pod Baranami ('Cellar under the Rams'; due to its location in the cellars of the Palace Under the Rams formerly owned by the aristocratic Potocki family). It was founded in 1956 by Piotr Skrzynecki, the student artist who had arrived from Łódź, fell in love with Kraków and stayed there for good.

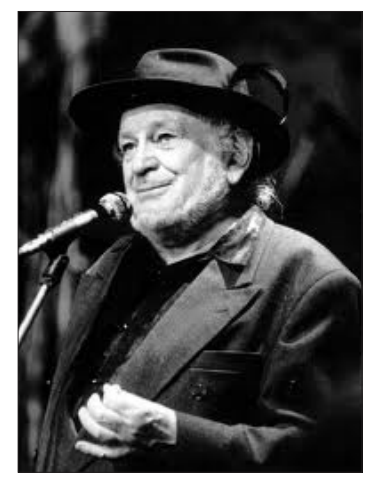

Figure 2. Piotr Skrzynecki. http: / / krakow.naszemiasto.pl/.
He was a true bohemian, living on literature and vodka and having no permanent residence anywhere, which brought him trouble from the communist authorities, who nonetheless allowed the cabaret to open and operate as a sign of new opening after the political thaw of the mid-1950s following the death of Stalin and changes in the Soviet Union. The cabaret was officially active until 1997, when Piotr Skrzynecki died, but then his fellow artists and friends continued the tradition. Regular performances, mainly of cabaret songs, have continued until the present day. In line with the Little Green Balloon tradition, the admission to the Cellar under the Rams performances was by invitation only, which was again understandable given the overwhelming political censorship, this time operated by the communist state.

And again the effect was the same as in 1905 - everybody wanted to be invited as this was the status symbol in the polite, conservative society of Kraków intellectuals, which was something completely different than the official circles of communist authorities. Every new performance was the subject of rumours across town, but only those who were there really knew the truth about it. The kind of rumours that spread then were different than back in 1905, as they now concerned the alleged illegal political jokes told openly during performances, and the spirit of freedom thriving there without restraint. The social gossip was definitely of lesser importance, although the cabaret strategy remained to cultivate the feeling of ingroup solidarity, which definitely enhanced the humour experience of those who were included (see Lockyer \& Myers 2011 for a discussion about sharing the comic experience as an important feature of live comedy shows).

The cabaret became such an influence that after 1989 it became established and appeared on large stages across the country and on national television. The cabaret offered songs and sketches (cf. e.g. http://www.youtube.com / watch?v=frg0sSCUEFg), each introduced by Piotr Skrzynecki as the compère, 
with his indispensable little bell, which he always held in his hand and rang as a sign that one number ended and another began (sometimes he was late to appear on the stage, so the bell was heard in the ensuing silence from well inside the artists rooms in the cellar, as Skrzynecki came running towards the audience, causing roars of laughter).

In spite of censorship, the cabaret indeed did not refrain from political satire, but did that intelligently so as to outwit the censors. One of the standard sketches were parodies, in the most famous of which official documents were set to music and sang, e.g. the letter Skrzynecki received by from the local militia station requesting him to pay a fine for loitering during the night, sleeping on a public bench, and shouting abuse at the militiamen who were trying to get him to show his documents. The singer would emphasise the particularly awkward phrases used in the letter as well as legal citations and references to binding laws, but there was nothing illegal in the performance, so the censorship could do nothing about it. Another standard procedure of Piotr Skrzynecki was to invite special guests of the performance - well-known public figures of Kraków, including some more open-minded government officials - onto the stage and make them the source of mild ridicule, which was, however, also the source of pride to them afterwards, as they felt accepted as members of the elite cabaret ingroup.

\section{Other cabarets of the communist times}

Another stream of the Polish cabaret in the 1960s and 70s was Kabaret Starszych Panów ('Elderly Gentlemen Cabaret'), which was the only cabaret running occasionally on television at the time. Understandably it was thoroughly non-political, but its retro-style, old-fashioned dresses, top hats and suits of the performers, combined with sophisticated conversations and texts of songs (cf. http://www.youtube.com/watch?v=prAtqmW7EVY) made a very clear political point, when contrasted with the prevailing egalitarian, working-class "culture" and brutishness forced by the communist authorities and their condemnation of pre-war aristocratic Poland.

Figure 3. Jeremi Przybora and Jerzy Wassowski in The Elderly Gentlemen Cabaret. TVP archives at http: / / tvp. info / informacje / kultura / starsi-panowie-patronaminiewinnych-czarodziejow/3360086.

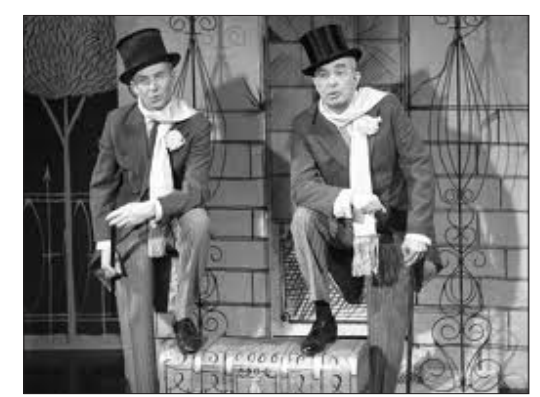


The lack of political references and the mild social satire, combined with many absurd, uninterpretable scenes and catchy songs, gave the audiences the muchwanted distance from the surrounding, rather depressing reality, a kind of cathartic experience (for a description of a similar effect, see also Laineste 2012, about the status of the Soviet estrada) as illustrated by these testimonies:

As [the comic writer] Wojciech Mtynarski recalls, when the consecutive evenings at the Elderly Gentlemen were broadcast, the streets of Polish towns and housing estates became deserted. [The song writer] Agnieszka Osiecka claimed she knew the family who particularly celebrated the communal watching of the Cabaret-they all dressed up smartly, and prepared a sumptuous candle-light supper to participate in the unreal world of Przybora and Wassowski at least for the moment... The audiences were charmed by the old-fashioned manners of $\mathrm{Mr} A$ and $\mathrm{Mr} B$, their elegance and pre-war culture of sorts, so much different from the grey reality of the Polish People's Republic. (Kiec 2004: 142-143; author's translation)

The Tey Cabaret of Poznań and Dudek of Warsaw, active from the 1960s to $1980 \mathrm{~s}$, continued the tradition of cabaret monologues, practiced in the Qui pro Quo before the war too. The individual performers acted the prepared monologue on stage, which was not necessarily literary, but almost always used polite language - very little obscenity was allowed on stage. The exceptions were one of the performers of Tey who played a working class character using some moderately saucy language as well as the Warsaw-based cabaret Pod Egida, which allowed itself some erotic reference as well even some strip performances. One of the most famous monologues performed repeatedly on stage was written by the Dudek ('Hoopoe') cabaret, which used the very familiar image of a notorious drunk, an especially common sight at the time of communism in Poland. The performer (Edward Dziewoński, cf. http://www.youtube. com/watch?v=fe8DLOsu6fM) acts a drunkard husband who is told by his wife to pour out the twelve bottles of juniper vodka he owns into the sink, which he dutifully does, except single glasses of each which he drinks. He recounts in detail how with his pouring out of each bottle he becomes increasingly drunk and things become fuzzy and the world whirls around him. The striking feature of the monologue is the highly elaborate, literary language used throughout, the final accent being the sweet complement offered to the wife. In contrast, the Tey cabaret used the seeming spontaneity as a performance technique, the performers themselves probably being slightly intoxicated, commenting tongue-in-cheek on political issues in colloquial language and with familiar references, parodying political slogans (cf. http://www.youtube.com/watch?v= 
f4O1iyJX0_w). The spontaneity, however, was rehearsed before (as is the case with contemporary stand-up comedy), although no doubt each performance had individual features due to the not entirely predictable audience reactions.

Another form of a literary cabaret was practiced by the radio show 60 minut na godzine ('60 minutes per hour') broadcast by the Elita cabaret in the years 1974-1981. The language used there was often colloquial mainly in order to parody the contemporary manners and corruption (e.g. of managers, academics or esp. of village doctors in the famous radio narrative "From a Young Doctor's Diary") or just enjoy the references to the patriotic trilogy of novels by the $19^{\text {th }}$-century writer Henryk Sienkiewicz in the new, twisted light. The latter were offered by the satirical radio drama known as Rycerzy Trzech ('The Three Knights'), the plots of which were taken from the novels and deprived of nationalistic import, focusing on the vices of principal male characters, such as cowardice, drunkenness, and greed, as well as the pursuit of beautiful ladies, the motives originally present but played down in the novels. In addition, the reality of $17^{\text {th }}$-century Poland depicted in the novels is mixed there with contemporary references and ways of thinking, while using the original archaic language of the novel is again mixed with contemporary colloquial idiom. The best known symbol of the cabaret was its signal song, "The Three Knights" (http:/www.youtube.com/ watch?v=3jP779Gr41Q). The popularity of the radio show led subsequently to televised stage performances by the same cabaret in $17^{\text {th }}$-century gentry costumes, the main focus of which was the parody of the original language of the novel (http://www.youtube.com/ watch?v=ccx4-KT_ACs\&feature=related).

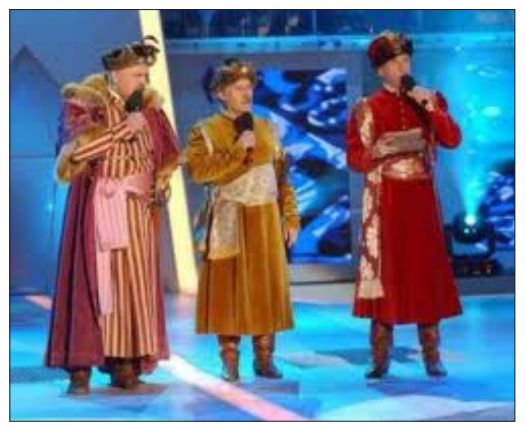

Figure 4. The Three Knights. Elita Cabaret. http: / /www.kabarety.com.pl/. 


\section{The cabaret and stand-up after the political change of 1989}

The political change of 1989 strongly affected the cabaret life of Poland as in the 1990s the cabarets, suppressed and restrained in the People's Republic of Poland, could thrive and proliferate. The National Cabaret Festival PAKA founded in 1985 and held every year in April, could now be partly rebroadcast on national television and newer and newer cabarets won the awards, leading to the emergence of strong cabaret groups in various cities, and even the cabaret centres, such as Zielona Góra in western Poland. The latter was created by a single person, Władysław Sikora, cabaret animator and teacher of the Pedagogical Academy, who stimulated at least a dozen new cabarets, which later made their name across the country. The major form of cabaret performance was an acted sketch as well as a cabaret song (cf. Błąd 2012), with only occasional acted monologues. The audiences had been used to group performances much more and having a prepared script was the rule. The improvised performance was allowed mainly in-between the sketches when the compère moved in. All this was not a very fertile ground for the development of the stand-up, which has been very strongly present and appreciated in Britain and the United States now the role-model countries in the newly independent Poland.

\section{Stand-up: The genre}

Let us have a short look at the genre of stand-up and the way it is defined by scholars. Oliver Double, himself a performer and a theoretician, sees the standup environment as "a single performer standing in front of an audience, talking to them with the specific intention of making them laugh" (Double 2005: 19). The three key factors for the stand-up performance in his view are

- Personality (joke is all about personality, self-expression);

- Direct communication with the audience;

- Present tense (situation-bound performance).

More specifically, stand-up features crucially include the ambiguity of identity of the performer - the audience must feel a degree of uncertainty as to their identity as either playing the characters or playing themselves (Double 2005: 73). Secondly, acting in stand-up has a different interpretation: it is not an observed and learnt and performed character, but it is a performance, often impromptu and spontaneous (Double 2005: 82), although, as indicated above, the spontaneity is often partly planned and rehearsed before. Thirdly, the 
language of performers becomes more common and they swear more on stage just to sound authentic. This is so because authenticity and "truth" is the crucial value and vital concept in modern stand-up comedy (Double 2005: 97). The seemingly spontaneous stand-up performer "exchanges energy" with the audience by getting them to react or by commenting on the lack of reaction or on individual reactions (Double 2005: 108; he also remarks that stand-up happens as if by magic and stand-up comedians are born with a stage talent, which is impossible to learn). The performer is also supposed to make the audience feel cultural or ethnic and linguistic kinship with him or her by making selected local references that the audience can pick up. And it is the genuinely spontaneous moments that seem to bring the greatest joy to stand-up audience in Double's opinion (2005: 180).

An interesting feature of stand-up which makes it different from cabaret is the demand to "push at the boundaries" of audience sensibilities, which would actually agree with the definition of high-brow comedy offered by Kuipers (2006: 84-85, see also my review of Kuipers in Chłopicki 2009). The practices used for that purpose by comedians include dividing the audience and addressing individuals, drawing them into a conversation, and possibly putting them down; challenging the audience's predictable views (a good stand-up comedian is not necessarily the one who is liked because his views conform to those of the audience); "shifting consensus" - making the audience change their minds while the performance is going on; putting down hecklers, who are keen to disrupt the performance; seemingly adjusting the level of the performance to the needs of the audience, but learning a lesson from the jokes that fall flat by commenting: "I have found your level"; as well as offering to the audience some comments (sometimes self-deprecating) on their own personality, habits or personal preferences (e.g. by telling sick jokes), which gives the audience some kind of immediate insight.

The stand-up in the form which is now popular in America and Britain was born in the 1960s, following the vaudeville and music hall tradition in Britain and was based on collaborative production of lines as opposed to completely prepared lines, on sequences of jokes (like consecutive songs in music hall) as opposed to delivering a fully coherent text, on playing with the voice and impersonating other characters (interestingly a feature of low-brow comedy in Kuipers' study (2006: 80-83)). The language traditionally used in comedy clubs, where stand-up actually developed and was practiced, was highly explicit as a way of achieving immediacy and authenticity, which aimed at the audience feeling that the performers use their idiom and that they share the language with them. One of the respondents that Kuipers quotes makes the reaction particularly clear: "It's quite coarse. It happens instantly and is sometimes so 
coarse that I just have to laugh. They call a spade a fucking shovel. They don't mess around, it's just simply humor" (Kuipers 2006: 95), although vulgarity cannot genuinely be equated with humour (see the discussion of Chafe 2007 below).

Stand-up in its Anglo-American form was influential in Poland on the wave of political changes in the 1990s and attempts were made in the late 1990s and the first decade of the $21^{\text {st }}$ century to bring this genre closer to the Polish audiences and freshen up the established world of Polish cabaret. It first had to be taught to interested comedians and so a stand-up school was established by one of the top cabaret performers, Grzegorz Halama, best known for his impersonations of the chicken farmer, Pan Józek, or bacteria on stage, as well as for his seemingly spontaneous parodies of NATO generals and other public figures.

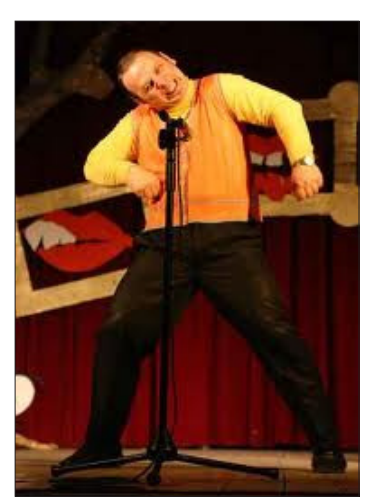

Figure 5. Grzegorz Halama, impersonating bacteria on stage. http: / / www.halama.pl.

A few comedy clubs appeared such as that of Piwnica $u$ Mariana ('The Cellar at Marian's') with such performers as Ela Wycech, who in her performances dwelt on women's topics and women's audiences (http://www. ipla.tv/Odcinek-6-ela-wycech/vod-5150450). The performances did not manage to join mainstream comedy, and one has an impression that the performer has a hidden feminist agenda, the presence of which the audiences in the 1990s seemed to resent, mindful of the communist propaganda. Nonetheless, this illustrates the tendency of stand-up in the British and American variety to push boundaries, which were referred to above. Another tendency is self-revelation of the performer, which in Wycech's case is self-deprecating humour with a focus on obesity and beauty as well as self-conscious humour on gynaecologists and the ridiculing of men (cf. however, the studies on self-deprecating humour used by women as strategy, e.g. Gray 1994; Horowitz 1997 or Lockyer 2011).

Another performer, this time a male, Cezary Jurkiewicz, focuses on personal topics too, offering a great deal of self-revelation to the audience, which could just as well be a revelation of the fictitious character Jurkiewicz impersonates. Stand-up principles require the audience to have a sense of ambiguity of who the actual persona is. His performance does not get too many laughs probably because the Polish audiences are still not used to hearing about the performer's own bad experiences, or are not very well versed in distinguishing between the performer and the fictitious persona. Jurkiewicz focuses on sex, drugs and religion as "his" topics, starting with self-deprecation too. Following a rather weak toilet joke, he says the following: 
Now the sixth anniversary of me being alone has passed. Lonely people have different priorities. What are important for me are erotic dreams [a few laughs]. Recently I had one of particularly good quality [a few laughs]. I saw my mother's face [stronger laughs] asking me what I wanted for breakfast. I said: Shit [no laughs]. I know my mother will always do what I want her to do.... [some laughs] (cf. http://www.youtube.com/ watch?v=aE1TBDl-rxk; all translations of stand-up extracts below are originally Polish, and the translations are author's)

Another problem is that the references to the taboos in a conversation require first the breaking of the ice and evoking the sense of commonality with the audience, which is not really achieved by Jurkiewicz as his stage persona is not very strong.

Still another performer, Krzysztof Unrug, opens his performance by a series of jokes which are supposed to liven up the audience and test their "level" and readiness to be amused.

Jesus Christ, a lamp in the floor [comment on the scenery; no laughs]. Welcome. That you... that you have come. God, it is so bright in here.... Revelation [no laughs]. Welcome in the pretty decoration, like from Szewcy ['Shoemakers'] by Witkacy. Shshshshs. Beer and music, you know the atmosphere [no laughs]. My name is Krzysztof Unrug. My mother says I am like this Honda of mine - small and loud and drinks a lot in town [a few scattered laughs]... Listen, this is a free event. This was funny [the audience laughs, encouraged by the performer's gestures]. (cf. http://www. youtube.com/watch?v=esc7UvxDhGA\&feature =related)

Later on in his performance he moves on to further self-revelation, focusing on gay jokes.

I recently attended the Equality Parade [= Gay Pride], so you know the second thing about me [a few laughs]. It is better and better [no laughs]. So I was at the parade of equality, why equality, I thought that it was diversity parade, or variety, somebody just made a blunder some time ago, and it stuck somehow [no laughs]. So I was at the parade and I really should have brought an airgun with me there [a few brief and rather alarmed laughs]. In what other way can you slay the fowl? [no laughs] All these feathers there... These people had cockatoo genes in them I am sure. If you send them to the New Guinea, the motherland of cockatoo, then all the cockatoo there go: "Oh, fuck, mutants [laughter]."

The final image is amusing due to its incongruity, and the performer definitely uses pushing the boundaries technique with regard to the subject as well as 
self-revelation (which seems genuine, and there is no reason why the audience should think he pretends, although the ambiguous identity was probably intended), and his content includes a series of jokes, rather than a coherent text.

The Polish stand-up is sometimes also offered in English, by Polish performers. This occurs in the Warsaw International Comedy Club, where the subjects are frequently toilet humour and generally self-deprecation humour. One Polish comedian performing there is known by the stage name of Not So Super Mario. The act starts with the little game with the band, which stops playing a bit too late and then prevents Mario from taking the floor by resuming playing whenever he wants to start talking. Following some nonverbal gags, he introduces himself using ironic and self-deprecating comments about himself as "the fattest member of the group. Basically, I am the only guy with no British, American, Australian, or what the fuck else origins." "We still love you, man." [comments somebody from the audience]. Then a toilet joke follows: "I had a funny situation today. I went to visit the Złote Tarasy toilet in Warsaw and there above the urinal there was a funny sticker: "Now you are holding the whole world in your hands." What a small fucking world," he comments. This is met with laughter and a rather long sequence follows when he describes (via self-revelation) his problem with urinating when somebody stands behind his back or next to him and describes an old guy standing next to him uttering strange sounds, and blocking his activity, and then mentions hearing somebody else masturbate in one of the cubicles. This is ignored by the audience, as cooperative as it is, having helped him before with the English term for urinal, which he did not know (cf. http://www.youtube.com/watch?v=eXKFG-2XU7s\&feature=related).

The performer hopes to raise laughter mainly due to obscenity and explicitness, which makes it rather disappointing, as the references to taboos and physiology are not sufficient to ensure comic effects (cf. Chafe 2007: 74-82, where he classifies profanity and scatology ("disgusting things") as examples of non-seriousness without humour) and work only for low-brow, working class audiences or children for that matter. Some cultures seem to be more tolerant of comic explicitness than others, and Anglo-Saxon cultures seem to be an example here (cf. e.g. Davies's (2002: 90-108) study of Australian humour).

There are other examples of Polish stand-up which I consider reasonably successful attempts, as they manage to stay away from explicitness and attempt some comic structure (double entendre, incongruity, imagery) in their performances. For instance, Rafał Rutkowski performs at one of the television shows from the series HBO Comedy Club ( $N a$ stojaka, a term which constitutes an attempt to translate stand-up into Polish), his topic being sex and language, and clearly tries that which Double called "shifting consensus" - trying to convince the audience to change their point of view. Having been introduced by 
the compère of the show and kicking the latter out of the stage by explaining to him what one-man show was, he starts rather abruptly:

Listen, I would like to refer to the subject that has been raised here before. Who out of you "cultivates" sex? ['uprawiać seks'; a standard collocation in Polish] [laughter] No, this was not meant to be funny. A serious question. Oh, there, bravo for you, sir [intense laughter]. Who else? No, not to worry, this is just for statistics. So listen, I do not cultivate sex [laughter], since I am not from the country [laughter]. And you can imagine, sex has always been regarded as something that elevates you, "gives you wings", and here we talk of sex as if we were talking about beetroots[laughter; impersonations]. "Hi, I am Zenek, I cultivate beetroots by profession." "Hi, I am Angela, I cultivate sex by profession." [laughter] "Nice, if you are interested you can come to us to the country as there are not many girls who know about cultivation." "So we could cultivate something together?" "Yes, but you know Angela, you would need to put something on, as the sun would burn your cunt ['bo ci słońce pizdę zjara'; vulgar/slang Polish expression] [intense laughter]. (http://www.youtube.com/watch?v=BH-MB0loIUs)

The act has comic structure (verbal ambiguity, reference to the audience stereotypical experience of the rural life and characters as well as to the common image of prostitutes), and the punch line seems surprising, although the female members of the audience visible in the clip seem rather embarrassed, while the male between them enjoys the gag thoroughly.

Another performer, Abelard Giza, makes use of non-verbal gags and refers to his somewhat Middle-Eastern appearance. He starts as follows:

Listen. I am glad this is not open air. Because in open air people do like this [he frowns; laughter] and you never know whether they like the performance or just are blinded by the sun [some laughter]. Listen. When I was entering the stage here, I bet that half of you thought: Yes, indeed, I would really like a kebab [laughter and clapping]. Yes, I know that very well. And the other half wondered whether the bomb I have under my shirt would blow up the entire building or just the first three rows [clapping]. Listen, this is not a bomb. This is my belly, which has recently got out of control and started to live a life of its own [limited laughter]. (cf. http:// www.youtube.com/watch?v=gN7Zy9OXpN4)

His topics are thus ethnicity, terrorism and drugs, and he makes use of real or pretended self-revelation (ambiguity of identity), immediacy achieved through apparently successful reading of the thoughts of the audience, and some limited self-deprecation (e.g. his Middle-Eastern appearance). 
The established Polish cabaret artists have rightly come to the conclusion that young talents should be sought for stand-up, and so a competition was started called Zabij mnie śmiechem ('Kill me with Laughter'), the final shows of which, with the winner and runner ups, are shown on television. Mariusz Kempa won one edition of the competition by selling his personality, or rather non-personality, and making jokes or more correctly meta-jokes (see Attardo 2001: 70-76 and his discussion of meta-jokes, which he also calls second degree jokes).

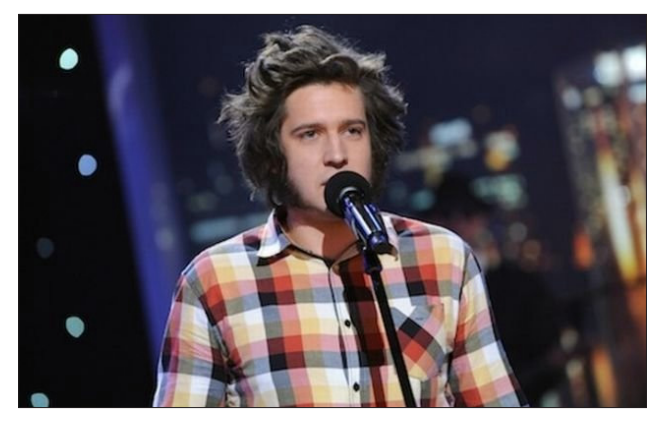

Figure 6. Mariusz Kempa, young stand-up comedian. www. plotek.pl.

He has a slow, rather unemotional voice. In his winning performance, he says "Good evening", and then walks around and around, and after a while he explains that if he does that he is a little less tense. Then he walks some more and says: "No, maybe I did too much of the walking." And he continues in the monotonous, slightly shaky voice, with ironic, somewhat self-deprecating remarks: "As a man of incomprehensible avant-garde of poor joke, I tend to have some idiosyncrasies on stage, this could be a hand at the back on the side of the ass [some laughs], this could be a cone in the pocket [he takes it out and shows it], but it could also be a piece of a cracker [he takes it out and eats it; some laughter and clapping]." He then focuses on his main idiosyncrasy of the evening, and stops talking and starts showing the large sheets of paper with writing on them. The idiosyncrasy is:

1) "Silence and",

2) "Awesome white sheets",

3) "Himalayas of avant-garde",

4) "Yes, the mute stand-up",

5) "First in Poland", 
6) "Second in the world",

7) "Right after Hungary",

8) "the stand-up for the shy"

(the showing of each sheet evokes laughter and sometimes clapping too;

cf. http://www.dailymotion.com/video/xfqdnv_michay-kempa-zabij-mnieymiechem-odc-8-finay_fun).

This performance meets the standards of stand-up (authenticity, colloquial language, personality, self-revelation, pushing at the boundary of the genre, later also picking on the jury), while also meeting the standards of cabaret - an obviously prepared performance, a monologue of sorts, and full appreciation of the audience (no attempts at heckling). It must be stressed again, however, that large proportion of stand-up comedy performances are also prepared in detail despite giving the impression to the contrary, thus the degree of preparedness cannot easily be considered the main point of divergence between the cabaret and stand-up.

In spite of all the examples above, many attempts at stand-up actually originate from the cabaret and in fact never leave its frame. The first example is the highly successful mime, Ireneusz Krosny (cf. his trilingual website, which lists his numerous tours; http://www.krosny.net/index3.htm), who has recently forayed into stand-up, one example of which is his "illustration" of the song by the singer named Feel with literal and sometimes figurative gestures accompanying the words of the song (cf. http://www.youtube.com/watch?v=UFNY_mbALWQ). The parody actually makes fun of the words usually accompanying pop songs, but he also plays very strongly on his personality and very expressive face and body.

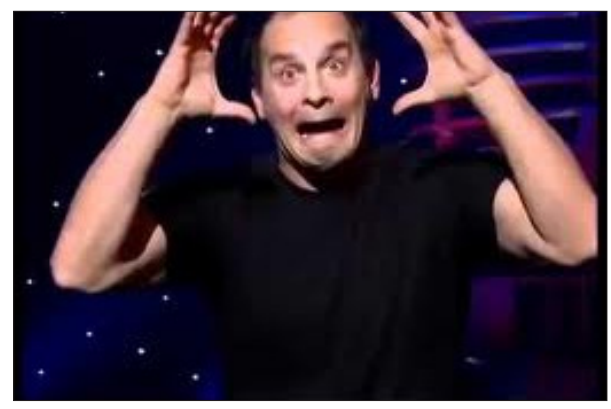

Figure 7. Ireneusz Krosny, the mime. www.humol.pl. 
The tradition of intelligent compères, whose personality is of crucial importance in their job, was taken up by the best compère of recent decades, Piotr Bałtroczyk, who also tries his skills as a cabaret performer himself. What is characteristic of Bałtroczyk is that he does not usually make use of selfdeprecation, but quite often ironic self-praise is his way to pave his way to the audience acceptance. One of his performances (as a guest on the Kill Me with Laughter show; http://www.youtube.com/watch?v=5VMTvfnM9NI) opens with an introduction, which goes as follows:

The unique [performer], whose handsomeness stimulates the most beautiful to weep [all this text coincides with clapping], he, the fame of the land of Warmia, the farmer from Warmia, whom you have missed most in this program-Piotr Battroczyk. Good evening, welcome to this air-conditioned room [laughter]. It is really great to be here on the stage of this theatre, the Jewish theatre [in Warsaw], because it is here that Jerzy Kryszak [one of the jurors listening to his performance] made his debut years ago, with the same hair [Kryszak is well known for his Einstein hair] and no moustache yet, as a little Jewish girl [laughter], with a matchstick in her hand, just one matchstick because her family was so poor [all this text coincides with clapping].

There is a strong sense of positive emotion in this extract (a dominant feature of Bałtroczyk, in general), which coexists with clear irony (exaggerated handsomeness and fame, etc.). When registered by the audience, however, the irony leads them to interpret the remarks as positive too (moderately handsome, moderately well known, etc.), which makes both the audience and the performer enjoy the situation, and give the impression they like each other (the same was actually attempted by Kempa, but his performance lacked the confidence of that of Bałtroczyk). The immediacy and authenticity of stand-up is there as Bałtroczyk is successful in pretending spontaneity, and relating to one of the jurors (Jerzy Kryszak) he follows the divide-the-audience rule, buy singling out one person to pick on. His speeches are always meticulously prepared, no matter how short they are.

Robert Górski is a member of one of the most successful cabarets in Poland of the last twenty years, the Moral Anxiety Cabaret, who made their name as a group dedicated to fighting stereotypical images of all kinds (cf. their website: http://kmn.k2.pl/news.php). All the members of the group are also active as individual actors and able to act as believable characters. They also stage monologues, and in one of the monologues (http://www.youtube.com/ watch?v=u9JLvX_iTyw) Górski is a working class character, a rather adroit and highly patriotic car thief, who brings all his personality to the act. On the way 
back from Germany with the stolen cars, they stop by a ski-jumping competition, where they want to support the Polish champion, Adam Małysz, and as they have no tickets they start digging a tunnel, but then manage to smuggle inside by stealing skis and outfit of one of the sportsmen who has fallen into the hole. One of the thieves is forced to take part in the competition, and the other acts as the trainer, killing time by selling various cars to the competitors ("I can sell any car to anyone") and in the end the terrified ski jumper unwittingly wins the competition, gets the crystal cup, but this time he falls into the hole they started digging before and breaks his legs. The slapstick narrative works as a monologue largely due to the bravado acting of Górski, the seemingly spontaneous story-telling and his personality too.

The last case in point is the monologue by the professional comic actor Cezary Pazura, who talks about health and health ads (http://www.youtube. com/watch?v=yS48rVKVnqw). He starts with short small talk to evoke positive emotion on the part of the audience:

How are you? Everything OK? The weather is great. Probably. I have not been outside for quite a while [laughter]. They locked me here so I stay put. ... Relax. I am not asking about your health, because I completely disbelieve in illnesses. I believe there are no illnesses. This is one global, gigantic conspiracy. They, they, by means of advertising on television, they talk us into believing symptoms, they are just symptoms, there are no illnesses, they talk us into believing symptoms to sell their pills, cough, running nose, sinuses, prostate..." [laughter].

He sells his personality (ambiguous identity) and performs the prepared monologue very naturally with greatly varying emphasis and an actor's voice, so the audience buys it. He also sells his name as the actor, which is very well known from the film, sitcom and television. Notably he tries to "shift consensus" with the audience trying to criticise the advertising business.

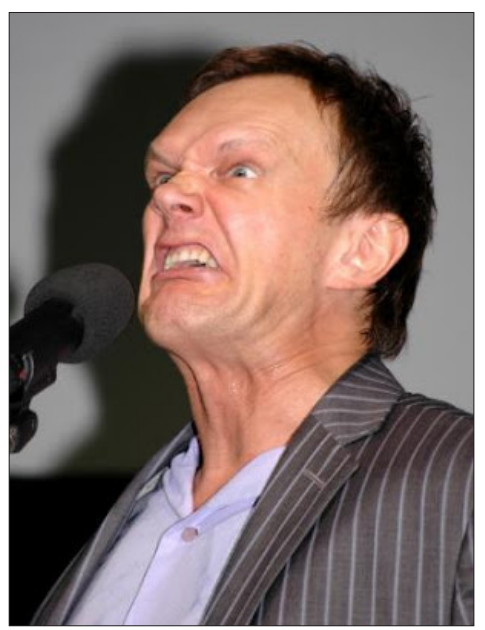

Figure 8. Cezary Pazura, popular comic actor. www.showbiz.blogspot. com. 


\section{Conclusion}

The strongly established cabaret tradition has clearly been winning in Poland over recently imported stand-up, which has been much less professional in terms of acting, as the former is performed by highly successful actors and cabaret artists, dwelling often on positive emotions, refraining from negative self-deprecating humour, and using colourful coherent narratives, rather than artificial sequences of jokes. Audiences are well used to the sketches performed by cabaret groups, which stage amusing scenes, perform comic songs or even monologues by cabaret artists, such as the one by Górski above. The structured, elaborate and smooth performances win easily over unstructured obscenity, which poses as stand-up, especially if it is performed by amateurs who are not necessarily very talented or experienced as stage performers.

I would like to emphasise the features of cabaret which win favour of audiences and prevail over stand-up in its own province: with regard to authenticity (seeming spontaneity, esp. idiomatic language), appealing personality, identity ambiguity (it is present in the sense that the performer is also a well-known personage, actor or celebrity, whom the audience knows from other roles), impersonations and storytelling skills (better actors do a better job), shifting consensus and pushing boundaries (this is considerably rare, though) or freshness of insight (e.g. bacteria on stage).

The criticism recently targeted at the cabaret is that its level has been generally lowered due to the needs of commercial media, esp. television, which answers the public demand to broadcast cabaret, popular as it has become, but at the same time limit their artistic freedom to uncomplicated and unchallenging humour, departing from the traditional literary routes. The sense of spontaneity and authenticity is necessary in cabaret, and although the Polish audiences are generally satisfied with prepared performances, there is a new trend, which is the genuinely authentic improvised stand-up, likely to take over the comedy stage in Poland, although not on television. The new trend is to organise evenings of improvised performance (especially in student clubs), where the rule of the day is the decision of the audience. It is them who dictate the subject of performance to the artists on the spot, and the artists take it upon themselves to meet the challenge and do their best to put up an improvised show. This is group stand-up in the best sense of the word, where intelligence and quick wit matter most, and reference to sex or scatological humour are a possible, but by no means necessary element. If this route is followed by young comedians, the current "tragic" state of stand-up may start to promise a more positive future for the genre. At the same time this would mean a return to the spontaneous and decadent,or to the beginnings of the Little Green Balloon cabaret.... 


\section{Sources}

http://tvp.info/informacje/kultura/starsi-panowie-patronami-niewinnych-czarodziejow/3360086, last accessed on 30 November 2012.

http://www.halama.pl, last accessed on 30 November 2012.

http://www.kabarety.com.pl, last accessed on 30 November 2012.

http://www.krosny.net/index3.htm, last accessed on 30 November 2012.

\section{References}

Attardo, Salvatore 2001. Humorous texts. Berlin: Mouton de Gruyter.

Błąd, Łukasz 2012. Cabaret in Poland. In: D. Brzozowska \& W. Chłopicki (eds.) Polish humour. Kraków: Tertium, pp. 175-220.

Chafe, Wallace 2007. The importance of not being earnest. Amsterdam, Philadelphia: John Benjamins.

Chłopicki, Władysław 2009. Book reviews: Paul Simpson, On the discourse of satire: Towards a stylistic model of satirical humour. Amsterdam, Philadelphia: John Benjamins, 2003; Giselinde Kuipers, Good humour, bad taste. A sociology of the joke. Berlin, New York: Mouton de Gruyter, 2006. Journal of Pragmatics 41, pp. 857-862.

Davies, Christie 2002. Mirth of nations. New Brunswick and London: Transaction.

Double, Oliver 2005. Getting the joke: The art of stand-up comedy. London: Methuen.

Gray, Frances 1994. Women and laughter. Basingstoke: Macmillan.

Horowitz, Susan 1997. Queens of comedy: Lucille Ball, Phyllis Diller, Carol Burnett, Joan Rivers, and the new generation of funny women. London and New York: Routledge.

Kiec, Izolda 2004. W kabarecie. [In the cabaret.] Wrocław: Wydawnictwo Dolnośląskie.

Kuipers, Giselinde 2006. Good humor, bad taste. A sociology of the joke. Berlin, New York: Mouton de Gruyter.

Laineste, Liisi 2012. Stand-up in Estonia: From Soviet estrada to Comedy Estonia. In: L. Laineste \& D. Brzozowska \& W. Chłopicki (eds.) Estonia and Poland. Creativity and tradition in cultural communication, Vol. 1. Tartu: ELM Scholarly Press, pp. 73-90.

Lockyer, Sharon \& Myers, Lynn 2011. 'It's about expecting the unexpected': Live standup comedy from the audiences' perspective. Participations: Journal of Audience and Reception Studies 8 (2), pp. 165-188.

Lockyer, Sharon 2011. From toothpick legs to dropping vaginas: Gender and sexuality in Joan Rivers' stand-up comedy performance. Comedy Studies 2 (2), pp. 113-123. 


\section{Władysław Chłopicki}

Wojtak, Maria 2012. Comic effects in the stage works of Aleksander Fredro. Transl. W. Chłopicki. In: D. Brzozowska \& W. Chłopicki (eds.) Polish Humour. Kraków: Tertium, pp. 57-78. 